\title{
Opportunities for Adaptive Learning Environments to Promote Sustainability-Oriented Innovation Competence in Vocational Education and Training
}

\author{
Florian Berding ${ }^{1}$, Andreas Slopinski ${ }^{1}$, Regina Frerichs ${ }^{1} \&$ Karin Rebmann $^{1}$ \\ ${ }^{1}$ Carl von Ossietzky University of Oldenburg, Oldenburg, Germany \\ Correspondence: Florian Berding, School of Computing Science, Business Administration, Economics, and Law, \\ Department of Vocational and Business Education, Carl von Ossietzky University of Oldenburg, Ammerländer \\ Heerstraße 114-118, 26129 Oldenburg, Germany. E-mail: Florian.Berding@uol.de
}

Received: December 3, 2020

doi:10.5539/jsd.v14n2p96
Accepted: January 18, $2021 \quad$ Online Published: March 6, 2021

URL: https://doi.org/10.5539/jsd.v14n2p96

\begin{abstract}
Achieving a sustainable economic system is a key challenge facing society. However, sustainable business to date has been only minimally considered when it comes to the requisites and curricula of business trainees. It generally has been left up to schools and teachers to provide their students with sustainable business skills. This involves creating teaching and training that effectively harmonize with learner requirements.

To support teachers in this process, the following develops a sustainability-oriented innovation competence typology using a latent profile analysis based on data gathered from 1,149 business trainees who were in the first, second, or third year of their apprenticeship. This typology can be used to plan and develop classroom teaching. Competency assessment was done using a multiple-choice test along with a questionnaire to determine students' beliefs about sustainable development.

The latent profile analysis revealed six groups of learner competence profiles, each of which require specific teaching when it comes to achieving sustainable innovation skills. Based on these, the following paper develops recommendations for specific teaching methods and lessons that effectively promote business trainee sustainability-oriented innovation competence, while at the same time including their specific requirements into teaching.
\end{abstract}

Keywords: adaptation; complex teaching-learning arrangements; sustainable economic activity; innovation competence

\section{Introduction}

Sustainable development can be understood as a game-changing shift describing the "giant ecological, technological, economic, institutional, and cultural shifts occurring at the start of the $21^{\text {st }}$ century" (Schneidewind, 2018). The objective of this transformation is an economic system factoring in the limits of the Earth to prevent irreversible damage to the global ecosystem and its negative consequences for humankind (WBGU, 2011). This includes a factor of justice, at the core of which is the process of ensuring economic and developmental opportunities for current and future generations (Schneidewind, 2018). Transformation like this is not automatic; it requires active participation by a number of different stakeholders (Schneidewind, 2018; WBGU, 2011). The essential role of the economy is emphasized here e.g., with the 17 UN Sustainable Development Goals (SDGs) (2015). Companies are clearly being challenged to make a significant contribution to sustainable development.

One opportunity to meet this challenge is the so-called business case for sustainability which sees the economic success of a company increasing via these kinds of deliberate activities, and whose purpose is to achieve ecological and social benefits (Beckmann \& Schaltegger, 2014). Ecological and socially beneficial activities in this business case are not understood as expensive chores done in addition to the actual core business, but instead as the specific steps taken that serve to boost a company's success (Schaltegger \& Hasenmüller, 2006). In everyday business, this means requiring employees to contribute to the development and implementation of this kind of operation through their professional activity.

The system of dual professional training in Germany where apprentices alternate their training between a 
classroom and company setting takes on the challenge of this professional action competence construct; its job is to provide society with qualified professionals who are able to effectively fulfill their tasks and requirements. Section 1 of the German Berufsbildungsgesetz (vocational training act) establishes that "Vocational training [...] must be done in a manner qualifying people to perform a profession within a changing world of employment and its required professional skills, knowledge, and abilities (professional capacity to act)." Although this law explicitly incorporates the changing world of work as a central element of dual business training in an attempt to integrate the requirements of sustainable development into it, sustainability aspects play a significant role neither in the company work part of an apprenticeship (Börner \& Brötz, 2015), nor for the time spent in the classroom (Fischer, 2007). In spite of these curricular deficits, vocational teachers still actively need to integrate the regulatory idea of sustainability into their lessons and promote sustainability-oriented innovation competence. Lesson planning models along with empirical study results from education-psychology diagnostics make clear in this context that the didactic-methodical formation of the teaching-learning process needs to be done based upon learners' requirements (Anders, Kunter, Brunner, Krauss \& Baumert, 2010; Helmke, 2015; Schrader, 1989). In an ideal world, there's no such thing as standard lessons for a class or group. Instead, the teaching-learning process succeeds based upon the respective individual learner requirements. From a more practical perspective, however, it is difficult to create lessons that are always specifically designed for each individual student. This requires a solution somewhere between these two extremes of standard lessons and individualized teaching.

One possible middle ground here could be the empirical development of learner groups brought together according to their individual requirements. Creating these kinds of groups reduces complexity for teaching staff when creating lessons, allowing them to plan manageable, effective teaching, providing lessons designed for the needs of the different learner groups (Berding, 2018). They are a compromise between addressing individuality on the one hand and practical considerations on the other. To date however, no findings exist regarding the requirements learners have when it comes to the topic of sustainability. And just how can teaching-learning processes be adapted to meet them? With this in mind, this paper poses the following questions for vocational business training and sustainability-oriented innovation:

(1) Which learner groups can be identified for teaching-learning processes and lesson planning?

(2) Which teaching-learning arrangements make sense for the individual groups when aiming to enable learners to achieve successful sustainability-oriented innovation?

To answer these questions, this paper will first present an approach applying the construct of sustainability-oriented innovation competence that will allow sustainable economic activity to be modeled. This draws from an empirical study on the development of learner groups that serves as the foundation for deriving the right teaching-learning arrangements. The results from this will guide the discussion on complex teaching-learning arrangements that allow for adaptive group lessons. The paper concludes with summarizing remarks.

\section{The Sustainability-Oriented Innovation Competence Model}

Implementing the business case for sustainability represents a major transformation, presenting those in the business world with new challenges and tasks. An orientation to this business case means understanding sustainable economic activity as a core of a company's business model and directing all work and business processes according to not only economic criteria, but ecological and social ones as well (Beckmann \& Schaltegger, 2014). From a sustainable economic perspective, profit here takes on a different role. Now, only those companies that are contributing to sustainability are rewarded and continue to thrive on competitive markets (Beckmann \& Schaltegger, 2014). The notion of people even changes, with a movement away from homo oeconomicus to homo sustinens (Bina \& Vaz, 2011). Bocken, Short, Rana and Evans (2014) developed concrete examples of sustainable business models, identifying eight different foundational approaches, all of which share the feature of requiring fundamental changes from companies, i.e., they necessitate the initiation of innovation processes.

Innovation is understood as the "goal-oriented implementation of new technological, economic, organizational, and social solutions to problems aiming to achieve business objectives in an innovative fashion" (Vahs \& Brem, 2015). From an economic perspective, solving a problem is understood as an innovation when it represents a reform from the perspective of the company in question (Hauschildt, Salomo, Schultz \& Kock, 2016). Innovations are clearly different from everyday routine activities (Hauschildt, Salomo, Schultz \& Kock, 2016). They are challenges requiring innovative solutions that generally do not have clearly defined starting points, final solutions, or even the required action steps in place to achieve a clear start to finish (Streicher, Maier, Frey, Jonas \& Kerschreiter, 2006).

In vocational training, professional competence is a useful target value for teaching-learning processes that explicitly aims to overcome these unclearly structured challenges. Reetz (2006) here sees "developed and mature 
potential for professional ability (...) allowing the individual to effectively operate in a specific professional situation." As opposed to qualifications, professional competence to act is characterized by how it enables an employee to overcome complex, upcoming, and unexpected challenges (Pätzold, 2006; Reetz, 1999). The professional competence required to achieve this contains a number of elements identified by Weinert (2001):

The theoretical construct of action competence comprehensively combines the respective intellectual abilities, content-specific knowledge, cognitive skills, domain-specific strategies, routines and subroutines, motivational tendencies, volitional control systems, personal value orientations, and social behaviors into a complex system. Together, this system specifies the prerequisites required to fulfill the demands of a particular profession, a social role, or a personal project (Boyatzis, 1982; Lévy-Leboyer, 1996).

This means that competence is more than mere knowledge; it also includes e.g., personal attitudes (Mulder \& Gruber, 2011).

Berding et al. (2018) examined the construct of professional action competence, developing it further based on studies from the fields of work science (Hardt, Felfe \& Hermann, 2011), innovation process research (Farr, Sin \& Tesluk, 2003), personality research (Jauk, Benedek \& Neubauer, 2014; Kandler et al., 2016; Stock, Hippel \& v. Gillert, 2016), as well as research work on epistemic cognition (Berding, 2015; 2016). Figure 1 shows this model.

\section{Sustainability-Oriented Innovation Competence}

The ability to identify, organize, and conduct ecologically and/or socially effective activities and contribute to economic success

\begin{tabular}{|c|c|}
\hline \multicolumn{1}{|c|}{ Professional Competence } \\
$\begin{array}{c}\text { Including professional knowledge about } \\
\text { sustainable business }\end{array}$ & $\begin{array}{c}\text { Personal Competence } \\
\text { Including ideas/beliefs about knowledge and its } \\
\text { acauisition as part of sustainable business }\end{array}$ \\
\hline
\end{tabular}

Figure 1. The model of sustainability-oriented innovation competence

The special role of professional competence in the model is a result of the fact that, without sufficient professional knowledge and ability, no connections to existing solutions can be identified, rendering it impossible to determine the achievability of new ideas. Personal competence is similarly necessary because innovation processes require a critical and open-minded attitude that is willing to challenge ideas. It should also be creative and independent when it comes to existing solutions, routines, and sets of knowledge (Hardt, Felfe \& Hermann, 2011). Personal competence is concretized into five sub-dimensions:

- Knowledge structure in sustainable economic activity: This continuum includes the description of beliefs that observe knowledge of sustainable economic activity as a mass of isolated factors; to views that that knowledge of sustainable economic activity is comprised of highly networked elements (Hofer \& Pintrich, 1997).

- Certainty about/stability of knowledge in sustainable economic activity: Ideas about the stability of knowledge describe a belief in absolute certainty about and unchangeability of knowledge of sustainable economic activity; to knowledge of sustainable economic activity as subject to continual development (Hofer \& Pintrich, 1997).

- Applicability of knowledge in sustainable economic activity: Beliefs about the applicability of knowledge range between the view that knowledge about sustainable economic activity does not contain any practical use to meet professional challenges; to the idea that knowledge of sustainable economic activity can greatly serve to overcome professional challenges (Zinn, 2013).

- Source of knowledge in sustainable economic activity: This continuum describes the view that knowledge lies outside of the individual; to the belief that knowledge of sustainable economic activity emerges as a result of individual constructions (Hofer \& Pintrich, 1997).

Justification of knowledge in sustainable economic activity: This dimension addresses the conditions that must be met allowing knowledge to exist from the viewpoint of the individual, and describes how an 
individual legitimizes something as knowledge. Borrowing from the model by King and Kitchener (1994), this continuum ranges between justification via observation and authorities, to legitimation by the own subjective opinion, all the way to justification through integration and assessment of documents, arguments, expertise, and authorities (Hofer, 2004). This sub-dimension describes how "knowledge of sustainable economic activity does not require legitimation" to the belief that knowledge of sustainable economic activity must be continually challenged and substantiated.

\section{Empirical Study}

\subsection{Instruments and Random Sample}

The Measuring Epistemic Beliefs in Sustainable Business Administration instrument by Berding et al. (2018) (IMEB-SBA) was applied for the operationalization of the personal competence sub-dimensions. This involved a survey form of 35 statements (e.g., "I believe that including ecological criteria such as environmentally friendly materials and short transport distances in the purchasing process influences marketing"). Here, participants expressed their level of agreement on a scale of 0 (completely disagree) to 6 (completely agree). The survey included a total of five scales representing each of the personal competence sub-dimensions. Higher values indicated innovation-promoting beliefs about sustainable economic activity. Cronbach's alpha here ranged between .714 and .875 .

Professional competence was measured with the help of the NaWi Wissenstest (sustainable economic activity test of knowledge) by Berding et al. (2018). With 15 tasks to complete, this test has proven itself among students as Rasch-compliant. Figure 2 shows one example of the tasks.

\begin{tabular}{|c|c|}
\hline & it play for a sustainable economic company? \\
\hline ם & $\begin{array}{l}\text { Profit is the primary goal of a sustainably oriented company. Company activity aims at profit } \\
\text { maximization. }\end{array}$ \\
\hline ם & $\begin{array}{l}\text { Profit is a foundational requirement for a sustainably oriented company. It serves to keep the company in } \\
\text { business for years to come. }\end{array}$ \\
\hline$\square$ & $\begin{array}{l}\text { Profit does not play a role for a sustainably oriented company. Social and ecological activities are the } \\
\text { primary focus. }\end{array}$ \\
\hline
\end{tabular}

Figure 2. The role of profit in a sustainable company

The test presented three possible solutions for each task, of which only one was correct. A maximum of 15 points were possible. These tasks covered a wide spectrum ranging from the foundations of sustainable economic activity (WCED, 1987), to the business case for sustainability (Beckmann \& Schaltegger, 2014) and strategies for the implementation of sustainable business (Hasenmüller, 2013), all the way to an awareness of assumptions about people (Siebenhüner, 2000).

A total of 1,149 business apprentices took the survey. The 643 women and 494 men (12 missing values) were $\mathrm{M}$ $=20.53(\mathrm{SD}=3.47)$ years old at the time they performed the test. They came from a number of different professions, including retail (274), industrial management (192), office management (156), as well as wholesale and foreign trade (151). 510 of the participants were in the first year of their apprenticeship, while 419 and 203 were in their second and third years, respectively. The following presents the survey results.

\subsection{Results}

Table 1 provides an overview of the results obtained by applying the instruments described above. With an average of nine out of fifteen possible points, the apprentices displayed a relatively high amount of knowledge about sustainable economic activity. They believe that knowledge of sustainable economic activity is relatively complex (structure), important when it comes to professional tasks (applicability) and can be challenged and requires legitimation (justification). When it comes to knowledge acquisition, they see both themselves as well as (professional) authorities (source) as capable of doing this and believe that knowledge within sustainable economic activity continues to fundamentally develop (certainty/stability). With the exception of the knowledge dimension of certainty/stability $(\mathrm{r}=-.118, \mathrm{p}<.01)$, the correlation between the apprenticeship year (first/second/third) and knowledge and/or attitude was not significant. The significant correlation was measured according to the values 
established by Cohen (1988) and should be rated as weak. As a result, the year of apprenticeship did not impact the test results.

Table 1. Minimum, maximum, and average competence dimension data

\begin{tabular}{|c|c|c|c|c|}
\hline Dimension & Min & $\operatorname{Max}$ & $M$ & $S D$ \\
\hline Knowledge about sustainable economic activity & 0 & 15 & 9.11 & 2.883 \\
\hline Source of knowledge about sustainable economic activity & 0 & 6 & 3.49 & 1.137 \\
\hline Structure of knowledge about sustainable economic activity & 0 & 6 & 3.77 & 0.941 \\
\hline $\begin{array}{l}\text { Applicability of knowledge about sustainable economic } \\
\text { activity }\end{array}$ & 0 & 6 & 3.88 & 1.154 \\
\hline $\begin{array}{l}\text { Certainty/security of knowledge about sustainable economic } \\
\text { activity }\end{array}$ & 1 & 5 & 3.75 & 0.837 \\
\hline Justification of knowledge about sustainable economic activity & 0 & 6 & 3.52 & 1.102 \\
\hline
\end{tabular}

A latent profile analysis was used to determine the amount of possible learner groups and their characteristics. A first step aimed to decide on the right amount of these learner groups. Table 2 presents key figures on this regarding the relative model quality.

Table 2. Data to determine relative model quality

\begin{tabular}{llllllll}
\hline & \multicolumn{3}{l}{ Information Criteria } & \multicolumn{2}{l}{ Significance Tests } & \multicolumn{2}{l}{ Quality Characteristics } \\
\hline How many & & & \multicolumn{2}{c}{ VLMR- } & Min. \\
groups & AIC & BIC & aBIC & Test & BLR-Test & Entropy & correlation \\
\hline 1 & 19582.322 & 19642.882 & 19604.766 & $/$ & $/$ & $/$ & .925 \\
2 & 18588.071 & 18683.957 & 18623.607 & $\mathrm{p}<.01$ & $\mathrm{p}<.01$ & .758 & .875 \\
3 & 18334.623 & 18465.836 & 18383.252 & $\mathrm{p}=.10$ & $\mathrm{p}<.01$ & .802 & .813 \\
4 & 18105.726 & 18272.265 & 18167.44 & $\mathrm{p}<.10$ & $\mathrm{p}<.01$ & .772 & .812 \\
5 & 17916.729 & 18118.595 & 17991.543 & $\mathrm{p}<.01$ & $\mathrm{p}<.01$ & .767 & .804 \\
6 & 17786.085 & 18023.277 & 17873.991 & $\mathrm{p}<.01$ & $\mathrm{p}<.01$ & .780 & .708 \\
7 & 17749.465 & 18021.984 & 17850.463 & $\mathrm{p}=.25$ & $\mathrm{p}<.01$ & .770 & .724 \\
9 & 17713.179 & 18021.025 & 17827.269 & $\mathrm{p}=.64$ & $\mathrm{p}<.01$ & .746 & .701 \\
\hline
\end{tabular}

Note: VLMR = Lo-Mendell-Rubin Test; BLR = Bootstrapped Likelihood Ratio Test (250 Samples)

$\mathrm{AIC}=$ Akaike Information Criterion; $\mathrm{BIC}=$ Bayesian Information Criterion; $\mathrm{aBIC}=$ Sample Size-Adjusted BIC

The AIC, BIC, and aBIC information criteria performed a comparison whose solution fit best to the comparatively smallest value (Bacher \& Vermunt, 2010; Rost, 2006). All three cases indicated a largest possible amount of nine learner groups.

On the other hand, a significant Vuong-Lo-Mendell-Rubin test (VLMR) along with a significant bootstrapped likelihood ratio test showed that the respective model with $k$ groups fit better than the model with $k$ - 1 groups (Geiser, 2013). The VLMR test indicated two to six groups, while the BLR test revealed the largest possible amount of nine learner groups.

The continued analysis therefore attempted to determine a solution of two, six, or nine learner groups. Additional important quality characteristics were included to help select between these three alternatives. Entropy described the extent to which the groups varied between one another (Celeux \& Soromenho, 1996). Values close to one indicated a good level of variation, while values close to zero indicated a poor level (Dias \& Vermunt, 2006; Geiser, 
2013). The median classification possibility, i.e., the probability that a person from group $k$ would also be in class $k$ should here be at least $80 \%$ (Rost 2004; 2006). The values in Table 1 show that this ratio decreased with an increasing amount of groups, and that the $80 \%$ minimum was not met with nine groups. So, because of the fact that the BLR test and the information criteria each showed as large an amount of learner groups as possible; because the solution with six groups showed better entropy values than the solution with two groups; and because the six-group solution met the $80 \%$ minimum requirement for median classification possibility, the analysis continued with six learner groups.

Upon determining the amount of learner groups, a second step needed to characterize them. Figure 3 provides the competence profile of the individual learner groups in the form of z-values. These were constructed in a way allowing 0 to always be the mean value and 1 the standard deviation. For the interpretation, this means that a zvalue of 0 corresponded to the average of the respective dimension in the entire random sample (Bühner \& Ziegler, 2009). Positive values indicated above-average characteristics, while negative values indicated below-average characteristics.

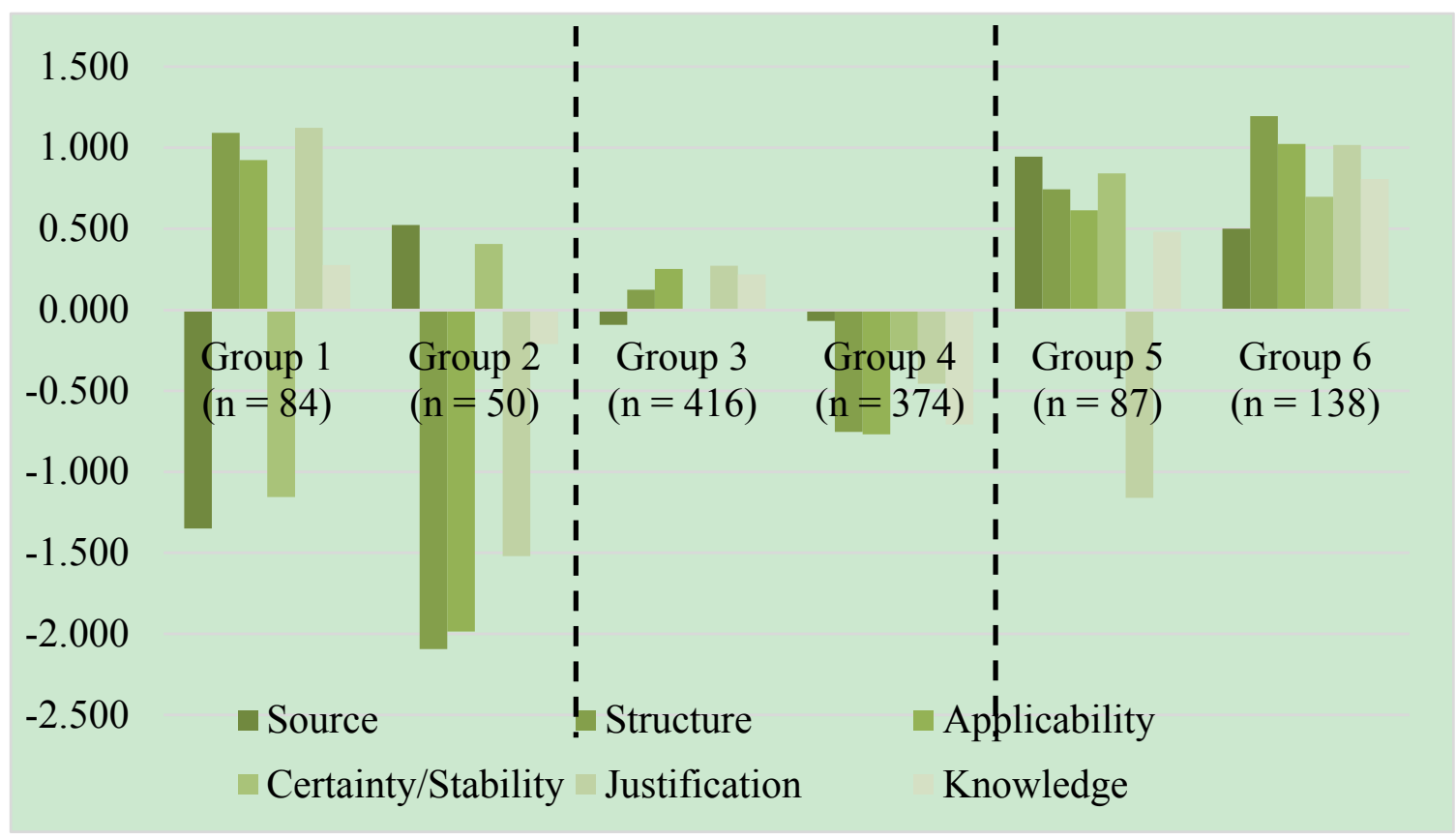

Figure 3. Competence profile of the individual learner groups (Z-values)

50 of the 1,149 apprentices were categorized into Group 1. Compared to the overall random sample average, this group of learners is characterized most of all by them understanding their knowledge of sustainable economic activity as comprised of simple, isolated elements. They believe that knowledge of sustainable economic activity has little or no importance for professional action and does not require legitimation. Additional, more secondary features of this learner group include their below-average knowledge about sustainable economic activity, even though they see themselves as creators of sustainability knowledge, feeling that knowledge of sustainable economics is a continually developing process. Because they see themselves as the solution for sustainability issues, while at the same time not recognizing the practical importance of them, this group of learners can be characterized as tending to reject sustainable business practice.

Comprised of 374 apprentices, Group 2 displayed below-average values in all the dimensions compared to the other groups. This means that they possess a comparably low amount of knowledge about sustainable economic activity, do not consider themselves to be creators of knowledge about it, understand knowledge about sustainable economic activity as something relatively simply structured and of no significant meaning for professional activity, and believe that knowledge about sustainable economic activity does not have to be justified and is not in a continual state of development. These learners are more moderate compared to Group 1 in terms of the applicability and complexity of sustainable solutions, meaning they can be seen as skeptics of the regulative notion of sustainable economic activity.

Most of the apprentices (416) belonged to Group 3, which is characterized by average competence in all of the 
dimensions.

With 84 apprentices, Group 4 learners displayed above-average values when it comes to the complexity, applicability, and justification of knowledge about sustainable economic activity; below-average values about the source of and certainty about it; and average knowledge about sustainable economic activity in general. This means that the learners believe strongly in the complexity, practical importance, and need to legitimize this knowledge, but do not see themselves as problem solvers of sustainable economic issues. They seek guidance for this from specialists and can in fact be described as "help seekers."

Group 5 (87 learners) was characterized by above-average values in all of the dimensions except justification of knowledge. They have an above-average knowledge of sustainable economic activity, see themselves as solvers of sustainability problems, believe in the complexity and practical importance of sustainable economic activity, and think that knowledge about it is something that continually develops. At the same time, these apprentices believe that knowledge about sustainable economic activity does not have to be justified, which means they can be characterized as possessing a regulative notion about it. And because of the low meaning attributed to legitimation, this group can also be categorized as normative.

With 138 apprentices, Group 6 was characterized by above-average values in all of the dimensions. These learners have the greatest amount of knowledge about sustainable economic activity, see it as able to be continually developed, see themselves as creators of new knowledge about it, and believe in the complexity, practical relevance, and need to legitimize knowledge of sustainable economic activity. This group of learners as a result achieves the highest level of sustainability-oriented innovation competence, meaning they can in fact be characterized as innovators.

With these characterizations in place, the following will discuss teaching-learning arrangements that can be customized to the specific groups and support them in their acquisition of sustainability-oriented innovation competence.

\section{Discussion}

What is better when it comes to helping learners achieve sustainability-oriented innovation competence: instruction-based or complex, constructivist teaching-learning arrangements? The empirical findings on the efficacy of complex learning arrangements are not fully clear (Hmelo-Silver, Dnuncan \& Chinn, 2007; Dochy, Segers, van den Bossche \& Gijbels, 2003).

Instruction-oriented approaches often prove themselves very effective when teaching the fundamentals and facts, while more complex methods appear to be superior when it comes to obtaining professional competencies and developing observational and analytical skills (Albanese \& Mitchell, 1993; Fölling-Albers, Hartinger \& MörtlHafizovic, 2004; Müller \& Eberle, 2009). Sustainability-oriented innovation competence is a complex constellation of cognitions and attitudes that need to be proven in the actual business world. This basically requires complex teaching-learning arrangements that are characterized most notably by learners' own initiative and constructs, and that are complemented by a practical- and problem-based orientation, not to mention the right kind of communication and interactions (Kopp \& Mandl, 2007; Rebmann, Tenfelde \& Schlömer, 2011; Reinmann \& Mandl, 2006).

\subsection{Company Explorations for Learners with Low Levels of Sustainability-Oriented Innovation Competence}

Groups 1 and 2 believe that knowledge about sustainable economic activity is comprised of isolated elements and is only minimally interconnected. They also feel it is not significant for business activity. These groups hardly acknowledge the potential of sustainable business models. They would be well-served by teaching-learning arrangements that heighten their sense of sustainable business activity using a sensory-discovery approach, allowing them to experience successful sustainable business models first-hand. This can be effectively achieved via company explorations.

Company explorations are teaching-learning arrangements that have learners leave the classroom environment to gather, evaluate, and communicate information from a company while posing the right kinds of specific questions (Rebmann, Tenflede \& Schlömer, 2011). Exploring a company as part of school learning has the objective of offering learners the chance to experience first-hand company activity which is otherwise outside of the immediate realm of what students are learning, and which in the classroom may only be theoretically learnable (Arndt, 2013; Kaiser \& Kaminski, 2012). Learners here help actively plan the company exploration by (1) determining focal points of the visit, developing the forms for the exploration and using them during the time spent at the company, and conducting interviews with employees and management; and (2) evaluating all of the information gathered, and applying the results into the overall concept of the learning situation and/or teaching (Gudjons, 2014). The 
focus here on specific issues and the active participation of learners makes a company exploration different from a mere company visit, which often tends to be a superficial, undifferentiated experience requiring only a passivereceptive role by the learners (Kaiser \& Kaminski, 2012; Slopinski, 2015). Key aspects need to be kept in mind when planning and evaluating company explorations in order to achieve the goals set for them. It first needs to be clarified whether the exploration is being done for orientation purposes, or to instead test and analyze specific learning facets. An orientation-based exploration primarily aims at the introduction to an object of learning as well as the development of motivation and up-front information about it that, following the exploration, will be more deeply examined and systematized in the classroom. The preparatory work in the classroom for this kind of exploration is relatively small, and the tasks to be completed as part of the company exploration are quite unspecific (Arndt, 2013; Kaiser \& Kaminski, 2012). A testing/analyzing exploration on the other hand is carefully prepared in the classroom to achieve a comparison via differentiated observational aspects between theoretically established facts and the actual company's everyday practice (Arndt, 2013; Kaiser \& Kaminski, 2012).

Both kinds of explorations are worthwhile when it comes to promoting sustainability-oriented innovation competence. Along with determining the right things to focus on, what is decisive for the success of the exploration is selecting the right company to explore. The company in question has to be willing to allow visitors to examine the company from within and encourage its employees to take time out of their workday for the learners (Arndt, 2013). The company also of course has to be one that successfully practices sustainable business. So, for company explorations that specifically aim to examine the promotion of sustainability-oriented innovation competence, the right place to go is to companies operating in line with sustainable entrepreneurship thinking, i.e., places that solve social and ecological problems by being successful in business (Schaltegger \& Wagner, 2011). Once the company exploration has been completed, the learners then need to summarize and analyze their experiences from it. Here it is essential to avoid an over-generalization of the exploration results, because the results from a single company are not (always) applicable to every other one (Kaiser \& Kaminski, 2012). So, a good idea here is then to collectively discuss, reflect upon, and view them through the lens of larger (e.g., national or international) contexts (Arndt, 2013).

\subsection{Business Games and Student Companies for Learners with Average Levels of Sustainability-Oriented Innovation Competence}

Although Groups 3 and 4 did not display specific needs in terms of supporting their sustainability-oriented innovation competence, they do in fact require assistance to develop ideas for achieving it. Companies can do a number of things here that allow employees to steer their professional activities towards regulative sustainability and participate in a sustainability-oriented company development (Haugh \& Talwar, 2010). In the classroom, schools can support and direct sustainability-oriented learning in particular via teaching-learning arrangements that simulate economic activity. This includes the use of company business games of a purely simulatory nature as well as student companies having a more real-world feel.

A business game is a teaching-learning arrangement applied to simulate the planning needed in situations requiring action and decision making. Situations here are examined that learners might otherwise not come into contact with, and are of an intransparent, complex nature (Blötz, 2015). Action and a "playing field" are prepared to simulate these kinds of situations for the learners, where they proceed to make decisions within predetermined roles both according to a set of rules and in experimental fashion. The decisions are then processed (typically using computer technology) and directly impact the following round of simulation, which sees the learners once again challenged to make well-thought-out decisions and accept their consequences and outcomes. This periodic approach makes business games particularly dynamic (Blötz, 2015; Bonz, 2009; Rebmann, 2001; Riedl \& Schelten, 2013).

As a variation of experimental games, business games offer vast potential for promoting sustainability-oriented innovation competence. They are able to show how companies are complex, economical, ecological, and social systems, and make clear the dynamics of company decisions and their interactions with market developments (Riedl \& Schelten, 2013). Learners are confronted here with specific market situations they have to evaluate and make company decisions based on them to achieve the right work and business processes (e.g., adapting production to changing demand). The effects on the market are simulated using the game model, which are then followed by the next wave of planning and decision situations (Bonz, 2009). As with the use of company explorations, the preparation and evaluation of business games is decisive for their learning success. The right game needs to be selected that promotes sustainability innovation competence, for example TOPSIM Corporate Social Responsibility, a spinoff from the TOPSIM family of business simulations (Gust \& Klabbers, 2015) or Sustainability Manager (Baumgartner \& Winter, 2013). Once the game has been completed, it should be reconstructed, analyzed, and evaluated to ensure learning success and promote learning transfer. This includes not only the exchange of experiences and their abstraction, but juxtaposing the business game with everyday business 
reality and/or company action as well (Rebmann, 2001; Riedl \& Schelten, 2013)

While business games are of a purely simulative nature, school companies tend to be closer to actual business reality. Student companies are "economically active institutions offering products and services on an anonymous market, seeking to at least cover their costs, if not achieve outright profit, while taking on a certain amount of risk" (Weber, 2011). It is mostly the learners who are responsible for the success of the student company. They actively operate as businesspeople, organizing their work and company flows by e.g., planning and organizing the purchase of goods, forming the own selling environment (sales floor, online platform, etc.), and creating quarterly and annual reports (see Finke 2001, p. 6). As opposed to other teaching companies, a student company has actual contact to other economic actors (customers, suppliers, etc.) (Kirchner \& Loerwald, 2014). Goods and finances really flow; there's an actual planning and creation of customer service; people are responsible for things; and an accounting department handles the financial paperwork. All of these are characteristic of working and learning in student companies (Nolte, 2006; Schlömer, 2013). There is, however, less of a business risk because although a student company is didactically and economically a real company, it is not a legal entity. It is instead handled as a recognized school project that can safely operate not only within a pedagogical arena, but as one that is protected from any possible legal ramifications as well (Weber, 2011). Student companies are very effective in allowing learners to plan, evaluate, and conduct business, and as a result analyze company situations by drawing from their own experiences and acquired knowledge (Weber, 2011).

With this promotion of sustainability-oriented innovation competence in mind, learners can also be motivated and enabled to interactively observe the economic, ecological, and social aspects of company activity, and develop and test business cases for sustainability (Loerwald \& Stemmann, 2011). Student companies are founded to achieve this, operating in accordance with a sustainability-oriented business model aiming to reach economic goals via a voluntary application of ecological and social accountability. The success of this kind of sustainability-oriented student company depends "most of all on a strong business idea, a strategy that works, and clear definition of foundational legal and organisational issues" (Schlömer, 2013). A sustainability-oriented student company greatly increases the business practice standard for learners. Now, the company not only has to achieve economic objectives; the learners are also required to consider the ecological and social aspects of the goods and services they offer, taking accountability for them. This requires them to among other things reflect upon what consumer and lifestyle patterns are transferrable in terms of intra- and intergenerational fairness (Henze, 2013). Doing this makes the learners select products and services and their corresponding purchasing, production, and sales processes that are in line with regulative sustainability thinking and that can be offered on the right kind of market. Determining success here goes beyond the calculation of simple business numbers such as profit that generally do not factor in ecological and social elements. Instead, instruments offering a greater array of perspectives such as the sustainability balanced scorecard (Figge, Hahn, Schaltegger \& Wagner, 2002) need to be applied. Learners running a sustainability-oriented student company furthermore need to be instructed in their use as part of business operations.

\subsection{Projects for Learners with Strong Sustainability-Oriented Innovation Competence}

The apprentices in Groups 5 and 6 displayed above-average sustainability-oriented innovation competence, and strong potential as candidates generating future sustainability-oriented company development innovation consistent with change agents for sustainability thinking (Berding, Slopinski \& Gebhardt, 2020).

These groups should be supported via practical, hands-on teaching-learning arrangements to further develop this competence. Projects opening the school up to cooperation with local companies (Emer and Lenzen, 2002; Euler, 2004) to develop sustainability-oriented innovations in the participating firms are "initiatives (...) where learners plan, achieve, and evaluate a problem and/or an authentic and complex challenge in groups to as great of an extent as possible on their own" (Rebmann, Tenfelde \& Schlömer, 2011). Another idea for promoting sustainabilityoriented innovation competence is having learners develop projects together with companies that have a business case for sustainability as their goal, and that allow learners a first-hand experience with actual company structures and culture. In Germany, these innovation projects have been developed by the Bundesinstitut für Berufsbildung (BIBB, Federal Institute for Vocational Education and Training) with funding from the Bundesministerium für Bildung and Forschung (BMBF, Federal Ministry of Education and Research) to achieve projects such as Innovationsmanagement and Innovationskompetenz für eine nachhaltige Entwicklung im Einzelhandel (InnoNE, Innovation Management and Competence for Sustainable Retail Development). This work has created materials and step-by-step guidelines laying the foundation for the different phases of innovation processes and their organization (Berding et al., 2017). An evaluation has shown the effectiveness of its teaching-learning concept in promoting sustainability-oriented innovation competence (Frerichs et al., in press). This concept applies to the structures of classroom-based business management project training as shown in Figure 4. 


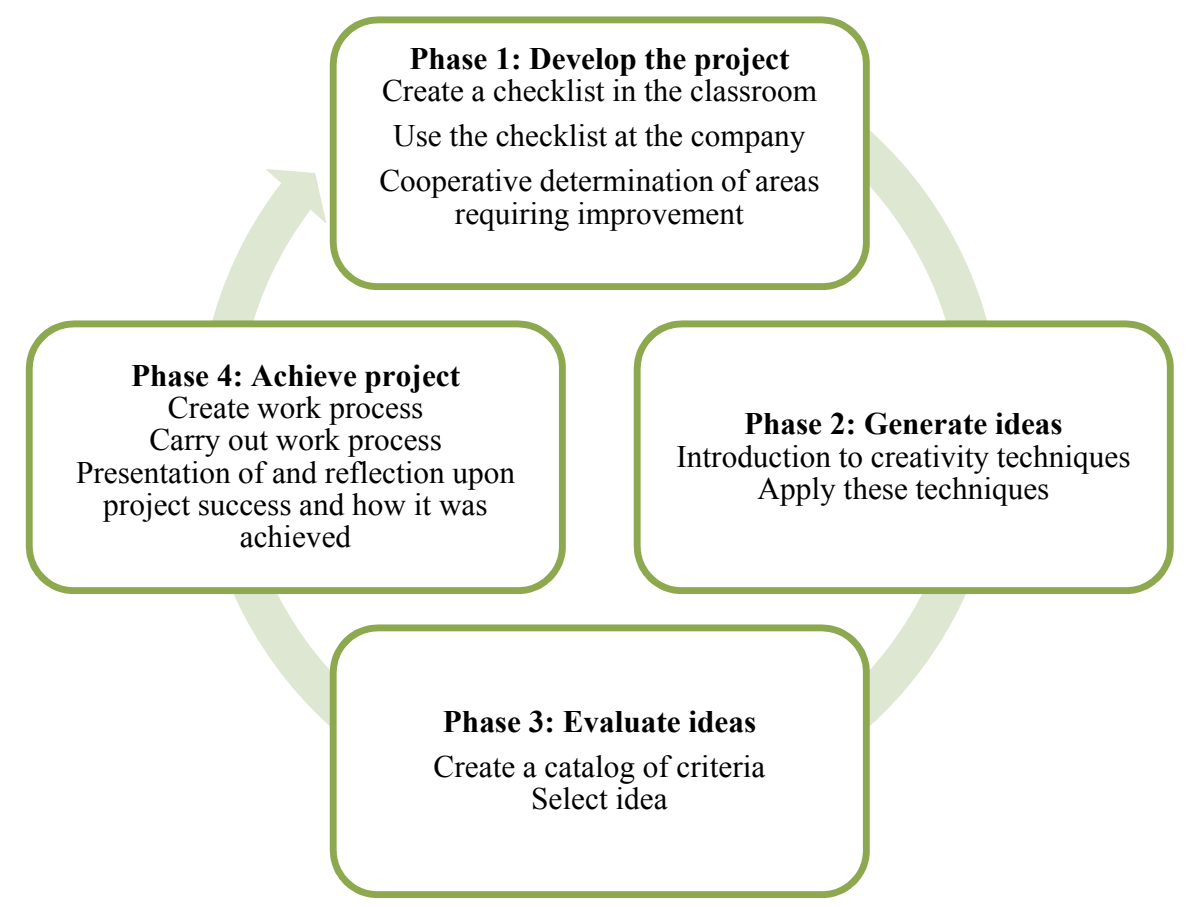

Figure 4. Business management project training

- Phase 1: The first phase has learners take an inventory of the company they will be working with in the project. The groups (5 and 6 ) here hav solid existing knowledge of sustainable economic activity, and therefore only require a brief review of it for application in the classroom. The learners then develop a checklist allowing them to analyze the company and how/if it sustainably operates in relation to the status quo. After analyzing the company with the checklist, the learners can then summarize the results in groups with the assistance of a concept map depicting the strengths and weaknesses of the company and their interplay. This aims to achieve the project's conscious selection of an area in the company requiring improvement.

- Phase 2: The second phase requires the development of ideas for improvement. Here the teacher confronts the project participants with good practice examples of sustainable economic activity, introducing the Hutwechselmethode into the teaching. The learners then independently apply this as a creative tool to help overcome static thinking patterns, achieve a wider perspective on the problems in question, and more effectively and conscientiously solve them as they generate ideas for a sustainability-oriented innovation project.

- Phase 3: The third phase involves evaluating the ideas and selecting one of them to be achieved in the project. Teachers can support this process by showing learners effective ways to apply sustainabilityoriented evaluation criteria. Essential here is the evaluation of economic, social, and ecological criteria, ensuring that all of them are addressed.

- Phase 4: The final phase sees the learners achieve the concept(s) selected. Gantt charts or precedence diagrams can help create and implement work plans and processes. This phase also requires a presentation of the project to both the class and the contact persons from the company being worked with. It furthermore includes (self-) reflection on the results obtained as well as an evaluative look back upon the project.

\section{Conclusion}

Vocational business training instructors have the important task of equipping their learners with the ability to achieve sustainable economic activity. Sustainability-oriented innovation competence offers a construct guiding teachers towards an adaptive learning environment. Although the adaptation to different learner groups can never be fully achieved for pragmatic reasons, it certainly is possible for instruction to be designed consistent with the 
requirements of relatively homogenous learner groups whose needs have been localized (Berding, 2018). Here it can be kept in mind that learners with lower levels of sustainability-oriented innovation competence can have their sense of sustainable economic activity strengthened by improving their notions of its importance. Company explorations can help achieve this. Learners having an average level of sustainability-oriented innovation competence can be supported by simulating business activity. An effective idea here includes the use of business games, as well as working and learning within student companies. Learning processes with real, very applicable experiences should be initiated for learners having a high level of sustainability-oriented competence, such as projects where learners work together with actual companies to generate sustainability-oriented innovations; these can be a very effective approach for creating the right didactical framework(s). Teaching-learning concepts to achieve this are available (Berding et al., 2017) and can be integrated into the classroom effectively.

\section{References}

Albanese, M. A., \& Mitchell, S. (1993). Problem-based Learning: A Review of Literature on its Outcomes and Implementation Issues. Academic Medicine 68, 52-81. https://doi.org/10.1097/00001888-199301000-00012

Anders, Y., Kunter, M., Brunner, M., Krauss, S., \& Baumert, J. (2010). Diagnostische Fähigkeiten und ihre Auswirkungen auf die Leistungen ihrer Schülerinnen und Schüler [Diagnostic skills and their effect on student achievement]. Psychologie in Erziehung und Unterricht 57(3), 175-193. https://doi.org/10.2378/peu2010.art13d

Arndt, H. (2013). Methodik des Wirtschaftsunterrichts [Methodology of economics education] Opladen: Budrich.

Bacher, J., \& Vermunt, J. K. (2010). Analyse latenter Klassen [Analysis of latent categories]. In C. Wolf, \& H. Best (Eds.), Handbuch der sozialwissenschaftlichen Datenanalyse (pp. 553-574). Wiesbaden: VS Verlag für Sozialwissenschaften. https://doi.org/10.1007/978-3-531-92038-2_22

Baumgartner, R. J., \& Winter, T. (2013). The Sustainability Manager: A Tool for Education and Training on Sustainability Management. Corporate Social Responsibility and Environmental Management 21(3), 167174. https://doi.org/10.1002/csr.1313

Beckmann, M., \& Schaltegger, S. (2014). Unternehmerische Nachhaltigkeit [Entrepreneurial sustainability]. In H. Heinrichs, \& G. Michelsen (Eds.), Nachhaltigkeitswissenschaften (pp. 321-367). Berlin: Springer. https://doi.org/10.1007/978-3-662-44643-0_9

Berding, F. (2015). Entwicklung eines Modells zur Beschreibung des Einflusses der epistemischen Überzeugungen von Lehrkräften auf den Aufgabeneinsatz im kaufmänmnischen Unterricht [The development of a model for describing the influcence of teachers' epistemic beliefs on their use of tasks in business education].bwp@28,1-30.

Berding, F. (2016). Welche Bedeutung haben epistemische Überzeugungen für Lernende in der beruflichen Bildung?[What is the importance of epistemic beliefs for learners in vocational education and training?] Zeitschrift für Berufs- und Wirtschaftspädagogik 112(1), 80-107.

Berding, F. (2018). Lernendentypen als Instrument zur Diagnose der Vorstellungen über Wissen und Wissenserwerb im Rechnungswesen und Marketing [Types of learners as a diagnostic instrument of expecations about knowledge and its acquisition in accounting and marketing]. Zeitschrift für Berufs- und Wirtschaftspädagogik 144(3), 467-495.

Berding, F., Slopinski, A., \& Gebhardt, R. (2020). Auszubildende als zukünftige Change Agents for Sustainable Innovations [Apprentices as future change agents for sustainable innovations]. Betriebswirtschaftliche Forschung und Praxis, 3, 313-337

Berding, F., Slopinski, A., Gebhardt, R., Heubischl, S., Kalmutzke, F., Schröder, T., Rebmann, K., \& Schlömer, T. (2018). Innovationskompetenz für nachhaltiges Wirtschaften und Instrumente ihrer Erfassung [Innovation competence for sustainable economics and instruments for its collection]. Zeitschrift für Berufs- und Wirtschaftspädagogik 114(1), 47-84.

Berding, F., Slopinski, A., Gebhardt, R., Heubischl, S., Rebmann, K., \& Schlömer, T. (2017). Die INE-Toolbox Ein integratives Instrumentarium für nachhaltigkeitsorientiertes Innovationsmanagement und Kompetenzentwicklung im stationären Einzelhandel [The ISD toolbox - An integrative instrument for sustainable innovation management and competence development in stationary retail].bwp@ 32, 1-24.

Bina, O., \& Vaz, S. G. (2011). Humans, environment and economics: From vicious relationships to virtuous responsibility. Ecological Economics 72, 170-178. https://doi.org/10.1016/j.ecolecon.2011.09.029 
Blötz, U. (2015). Das Planspiel als didaktisches Instrument [Business games as a didactical instrument]. In U. Blötz (Eds.), Planspiele und Serious Games in der beruflichen Bildung (5th ed., pp. 13-26). Bonn: Bundesinstitut für Berufsbildung.

Bocken, N. M. P., Short, S. W., Rana, P., \& Evans, S. (2014). A literature and practice review to develop sustainable business model archetypes. Journal of Cleaner Production 65(15), 42-56. https://doi.org/10.1016/j.jclepro.2013.11.039

Bonz, B. (2009). Methoden der Berufsbildung (2nd ed.) [Methods for vocational education]. Stuttgart: Hirzel.

Börner, M., \& Brötz, R. (2015). Nachhaltige Entwicklungsziele in der kaufmännischen Berufsausbildung Situationsbeschreibung und Perspektiven einer naturgemäßen Berufsbildung [Sustainable development goals in commercial vocational training - description of the situation and perspectives of nature-based vocational training]. In R. Brötz, \& F. Kaiser (Eds.), Kaufmännische Berufe - Charakteristik, Vielfalt und Perspektiven (pp. 245-264). Bonn: BIBB.

Bühner, M., \& Ziegler, M. (2009). Statistik für Psychologen und Sozialwissenschaftler [Statistics for psychologists and social scientists]. München: Pearson.

Celeux, G., \& Soromenho, G. (1996). An entropy criterion for assessing the number of clusters in a mixture model. Journal of Classification, 13(2), 195-212. https://doi.org/10.1007/BF01246098

Cohen, J. (1988). Statistical Power Analysis for the Behavioral Sciences (2nd ed.). New York: Psychology Press.

Dias, J. G., \& Vermunt, J. K. (2006). Bootstrap Methods for measuring Classification Uncertainty in Latent Class Analysis. In A. Rizzi, \& M. Vichi (Eds.), Proceedings in computational statistics (pp. 31-41). Heidelberg: Springer. https://doi.org/10.1007/978-3-7908-1709-6_3

Dochy, F., Segers, M., van den Bossche, P. M., \& Gijbels, D. (2003). Effects of problem-based learning: A metaanalysis. Learning and Instruction 13, 533-568. https://doi.org/10.1016/S0959-4752(02)00025-7

Emer, W., \& Lenzen, K.-D. (2002). Projektunterricht gestalten - Schule verändern [Designing project-based teaching - Changing school]. Baltmannsweiler: Schneider.

Euler, D. (Hrsg.). (2004). Handbuch der Lernortkooperation, Band 1: theoretische Fundierungen [Handbook of Learning Site Cooperation, Volume 1: Theoretical Foundations]. Bielefeld: Bertelsmann.

Farr, J. L., Sin, H.-P., \& Tesluk, P. E. (2003): Knowledge Management Processes and Work Group Innovation. In L. V. Shavinina (Ed.), The international handbook on innovation (pp. 574-586). Oxford: Elsevier. https://doi.org/10.1016/B978-008044198-6/50039-5

Figge, F., Hahn, T., Schaltegger, S., \& Wagner, M. (2002). The sustainability balanced scorecard - Linking sustainability management to business strategy. Business Strategy and the Environment, 11, 269-284. https://doi.org/10.1002/bse.339

Finke, A. (2001). Eine Firma für unsere Schule [A company for our school]. Göttingen: IBBW.

Fischer, A. (2007). Welche Möglichkeiten haben berufsbildende Schulen, Nachhaltigkeit zu thematisieren? [What opportunities do vocational schools have to discuss susainability?]. In A. Fischer, \& K. Hahne (Eds.), Strategien und Umsetzungspotentiale einer Berufsbildung für nachhaltige Entwicklung (pp. 41-53). Bielefeld: Bertelsmann.

Fölling-Albers, M., Hartinger, A., \& Mörtl-Hafizovic, D. (2004). Situiertes Lernen in der Lehrerbildung [Situated learning in teacher trainings]. Zeitschrift für Pädagogik, 50(5), 727-747.

Frerichs, R., Berding, F., Slopinski, A., Heubischl, S., Rebmann, K., \& Schlömer, T. (in press). Die Verbindung individuellen und organisationalen Lernens mittels der INE-Toolbox [The connections between individual and organizational learnings through the ISD toolbox].

Geiser, C. (2013). Data Analysis with MPlus. New York: Guilford Press.

Gudjons, H. (2014). Handlungsorientiert lehren und lernen (8th ed.) [Action-oriented teaching and learning]. Bad Heilbrunn: Klinkhardt.

Gust, M., \& Klabbers, J. H. G. (2015). Computerunterstützte Gruppen-Planspiele [Computer-supported group business games]. In U. Blötz (Ed.), Planspiele und Serious Games in der beruflichen Bildung (5th ed., pp. 84-103). Bonn: Bundesinstitut für Berufsbildung.

Hardt, J. V., Felfe, J., \& Hermann, D. (2011). Innovationskompetenz [Innovation competence]. Zeitschrift für Arbeitswissenschaft 65(3), 235-243. https://doi.org/10.1007/BF03373841 
Hasenmüller, P. (2013). Herausforderungen im Nachhaltigkeitsmanagement [Challenges in sustainability management]. Wiesbaden: Springer. https://doi.org/10.1007/978-3-658-02696-7

Haugh, M. H., \& Talwar, A. (2010). How Do Corporations Embed Sustainability Across the Organization? Academy of Management Learning \& Education, 9(3), 394-396. https://doi.org/10.5465/AMLE.2010.53791822

Hauschildt, J., Salomo, S., Schultz, C., \& Kock, A. (2016). Innovationsmanagement (6th ed.) [Innovation management]. München: Vahlen. https://doi.org/10.15358/9783800647293

Helmke, A. (2015). Unterrichtsqualität und Lehrerprofessionalität. Diagnose, Evaluation und Verbesserung des Unterrichts (6th ed.) [Teaching quality and teacher professionalism. Diagnosis, evaluation and improvement of teaching]. Seelze: Kallmeyer.

Henze, C. (2013). Lernen und Gestalten in Nachhaltigen Schülerfirmen [Learning and Designing in Sustainable Student Companies]. In G. de Haan (Eds.), Handreichung Nachhaltige Schülerfirmen, Band 1 (pp. 1-48). Berlin: Institut Futur.

Hmelo-Silver, C. E., Duncan, R., \& Chinn, C. (2007): Scaffolding and achievement in problem-based and inquiry learning: A response to Kirschner, Sweller, and Clark (2006). Educational Psychologist, 42(2), 99-107. https://doi.org/10.1080/00461520701263368

Hofer, B. K. (2004). Exploring the dimensions of personal epistemology in differing classroom contexts: Student interpretations during the first year of college. Contemporary Educational Psychology, 29(2), 129-163. https://doi.org/10.1016/j.cedpsych.2004.01.002

Hofer, B. K., \& Pintrich, P. R. (1997). The development of epistemological theories: Beliefs about knowledge and knowing and their relation to learning. Review of Educational Research, 67(1), 88-140. https://doi.org/10.3102/00346543067001088

Jauk, E., Benedek, M., \& Neubauer, A. C. (2014). The road to creative achievement: A latent variable model of ability and personality predictors. European Journal of Personality, 28(1), 95-105. https://doi.org/10.1002/per.1941

Kaiser, F.-J., \& Kaminski, H. (2012). Methodik des Ökonomieunterrichts (4th ed.) [Methodology of teaching economics]. Bad Heilbrunn: Klinkhardt.

Kandler, C., Riemann, R., Angleitner, A., Spinath, F. M., Borkenau, P., \& Penke, L. (2016). The nature of creativity: The roles of genetic factors, personality traits, cognitive abilities, and environmental sources. Journal of Personality and Social Psychology, 1-63. https://doi.org/10.1037/pspp0000087

King, P. M., \& Kitchener, K. S. (1994). Developing reflective Judgment. Understanding and Promoting intellectual Growth and critical Thinking in Adolescence and Adults. San Francisco: Jossey-Bass.

Kirchner, V., \& Loerwald, D. (2014). Entrepreneurship Education in der ökonomischen Bildung [Entrepreneurship Education in Economic Education]. Hamburg: Joachim Herz Stiftung.

Kopp, B., \& Mandl, H. (2007). Kooperatives Lernen wofür? - Welche Potenziale besitzt kooperatives Lernen? [Cooperative learning for what? - What potential does cooperative learning have?]. Zeitschrift für Berufs- und Wirtschaftspädagogik Beiheft, 21, 17-29.

Loerwald, D., \& Stemmann, A. (2011). CSR-Maßnahmen in Schülerfirmen [CSR actions for student companies]. Unterricht Wirtschaft + Politik, 1(3), 38-45.

Mulder, R. H., \& Gruber, H. (2011). Die Lehrperson im Lichte von Professions-, Kompetenz- und Expertiseforschung - die drei Seiten einer Medaille [The teacher in the light of research on profession, competence and expertise - the three sides of the same coin]. In O. Zlatkin-Troitschanskaia (Eds.), Stationen empirischer Bildungsforschung (pp. 428-438). Wiesbaden: VS Verlag für Sozialwissenschaften. https://doi.org/10.1007/978-3-531-94025-0_30

Müller, C., \& Eberle, F. (2009). Implementation von Problem-based Learning [Implementation of problem-based learning]. Zeitschrift für Berufs- und Wirtschaftspädagogik, 105(1), 53-69.

Nolte, M. (2006). Wirtschaft-live-Projekte in Berufsfachschulen - Wirtschaft [Economy-live projects in vocational schools - Economy].bwp@10,1-12.

Pätzold, G. (2006). Berufliche Handlungskompetenz [Vocational action competence]. In F.-J. Kaiser, \& G. Pätzold (Eds.), Wörterbuch der Berufs- und Wirtschaftspädagogik (2nd ed., pp. 72-74). Bad Heilbrunn: Klinkhardt. 
Rebmann, K. (2001). Planspiel und Planspieleinsatz [Business games and their implementation]. Hamburg: Kovač.

Rebmann, K., Tenfelde, W., \& Schlömer, T. (2011). Berufs- und Wirtschaftspädagogik (4th ed.) [Vocational and business education]. Wiesbaden: Gabler. https://doi.org/10.1007/978-3-8349-6375-8

Reetz, L. (1999). Zum Zusammenhang von Schlüsselqualifikationen - Kompetenzen - Bildung [On the connection between key qualifications - competences - education]. In T. Tramm, D. Sembill, F. Klauser, \& E. G. John (Eds.), Professionalisierung kaufmännischer Berufsbildung (pp. 32-51). Frankfurt am Main: Lang.

Reetz, L. (2006). Kompetenz [Competence]. In F.-J. Kaiser, \& G. Pätzold (Eds.), Wörterbuch der Berufs- und Wirtschaftspädagogik (2nd ed., pp. 305-307). Bad Heilbrunn: Klinkhardt.

Reinmann, G., \& Mandl, H. (2006). Unterrichten und Lernumgebungen gestalten [Teaching and designing learning environments]. In A. Krapp, \& B. Weidenmann (Eds.), Pädagogische Psychologie (5th ed., pp. 613-658). Weinheim: Beltz.

Riedl, A., \& Schelten, A. (2013). Grundbegriffe der Pädagogik und Didaktik beruflicher Bildung [Basic concepts of pedagogy and didactics of vocational training]. Stuttgart: Steiner.

Rost, J. (2004). Lehrbuch Testtheorie - Testkonstruktion (2nd ed.) [Textbook Test Theory - Test Construction]. Bern: Hans Huber.

Rost, J. (2006). Latent-Class-Analyse [Analysis of the latent class]. In F. Petermann, \& M. Eid (Eds.), Handbuch der Psychologischen Diagnostik (pp. 275-287). Göttingen: Hogrefe.

Schaltegger, S., \& Hasenmüller, P. (2006). Nachhaltiges Wirtschaften aus Sicht des „Business Case of Sustainability" [Sustainable business from the perspective of the "Business Case of Sustainability"]. In E. Tiemeyer, \& K. Wilbers (Eds.), Berufliche Bildung für nachhaltiges Wirtschaften (pp. 71-86). Bielefeld: Bertelsmann.

Schaltegger, S., \& Wagner, M. (2011). Sustainable entrepreneurship and sustainability innovation: categories and interactions. Business Strategy and the Environment, 20(4), 222-237. https://doi.org/10.1002/bse.682

Schlömer, T. (2013). „... das rechnet sich!“ - Wir bringen unsere Nachhaltige Schülerfirma ins Geschäft! ["... it pays off!" - We put our Sustainable Student Company into business!]. In G. de Haan (Ed.), Handreichung Nachhaltige Schülerfirmen, Band 3 (pp. 1-55). Berlin: Institut Futur.

Schneidewind, U. (2018). Die große Transformation [The big transformation]. Frankfurt am Main: Fischer.

Schrader, F.-W. (1989). Diagnostische Kompetenz von Lehrern und ihre Bedeutung für die Gestaltung und Effektivität des Unterrichts [Diagnostic competence of teachers and its importance for the design and effectiveness of teaching]. Frankfurt am Main: Lang.

Siebenhüner, B. (2000). Homo sustinens - towards a new conception of humans for the science of sustainability. Ecological Economics, 32(1), 15-25. https://doi.org/10.1016/S0921-8009(99)00111-1

Slopinski, A. (2015). Betriebsbesichtigungen in der nicht-akademischen Berufsbildung [Company visits in nonacademic vocational training]. In J.-P. Pahl (Ed.), Lexikon Berufsbildung (pp. 276-277). Bielefeld: Bertelsmann.

Stock, R. M., Hippel, E. v., \& Gillert, N. L. (2016). Impacts of personality traits on consumer innovation success. Research Policy, 45(4), 757-769. https://doi.org/10.1016/j.respol.2015.12.002

Streicher, B., Maier, G. W., Frey, D., Jonas, E., \& Kerschreiter, R. (2006). Innovation. In H.-W. Bierhoff, \& D. Frey (Eds.), Handbuch der Sozialpsychologie und Kommunikationspsychologie (pp. 565-574). Göttingen: Hogrefe.

Vahs, D., \& Brem, A. (2015). Innovationsmanagement (5th ed.) [Innovation management]. Stuttgart: Schäffer Poeschel.

Vereinte Nationen. (2015). Transformation unserer Welt: die Agenda 2030 für nachhaltige Entwicklung [Transforming our world: the 2030 Agenda for Sustainable Development]. Retrieved August 14, 2018, from http://www.un.org/Depts/german/gv-70/band1/ar70001.pdf

WCED (World Commission on Environment and Development). (1987). Our common future. Retrieved August 18, 2017, from http://www.un-documents.net/our-common-future.pdf

Weber, B. (2011). Schülerfirmen als Gegenstand und Methode ökonomischer Bildung [Student companies as a subject and method of economic education]. In T. Retzmann (Ed.), Methodentraining für den Ökonomieunterricht I (2nd ed., pp. 185-204). Schwalbach/Ts.: Wochenschau. 
Weinert, F. E. (2001). Concept of Competence. In D. S. Rychen, \& L. H. Salganik (Eds.), Defining and selecting key competencies (pp. 45-65). Seattle: Hogrefe.

WGBU (Wissenschaftlicher Beitrat der Bundesregierung Globale Umweltveränderungen). Hauptgutachten. Welt im Wandel. Gesellschaftsvertrag für eine große Transformation (2nd ed.) [Main Report. World in Transition. Social contract for a great transformation]. WBGU: Berlin.

Zinn, B. (2013). Überzeugungen zu Wissen und Wissenserwerb von Auszubildenden [Beliefs about knowledge and knowledge acquisition of trainees]. Münster: Waxmann.

\section{Copyrights}

Copyright for this article is retained by the author(s), with first publication rights granted to the journal.

This is an open-access article distributed under the terms and conditions of the Creative Commons Attribution license (http://creativecommons.org/licenses/by/4.0/). 